\title{
Identification of Prehistoric Park Leang-leang for the Historical Tourism Destination as Maros Promotion
}

\author{
Ismail Suardi Wekke \\ Institut Agama Islam Negeri (IAIN) Sorong, Indonesia \\ Asosiasi Dosen Insan Cita, Indonesia \\ The Jusuf Kalla Research Center for Cultural Studies, Universitas Muslim Indonesia \\ iswekke@gmail.com \\ Muhammad Makbul \\ Institut Sains dan teknologi An-Nuriyah Makassar, Indonesia \\ $\underline{\text { makbulm013@gmail.com }}$ \\ Amen Rais \\ Institut Sains dan teknologi An-Nuriyah Makassar, Indonesia \\ aminraisamr@gmail.com \\ Zulkfli Makmur \\ Sekolah Tinggi Agama Islam Darul Dakwah Wal Irsyad Kota Makassar, Indonesia \\ zmakmur@staiddimakassar.ac.id \\ Sirojjuddin Sirojjuddin \\ Universitas Pendidikan Muhammadiyah Sorong, Indonesia \\ ssirajuddin@unimudasorong.ac.id
}

\begin{abstract}
The purpose of this study is to analysis tourist attractions in Maros Regency, namely the Leang-leang prehistoric site related to the conditions, facilities, and infrastructure, as well as obstacles and challenges in their development. In addition, to be able to know the facts that have been raised by the researcher. It is undeniable that when conducting a research, there are always obstacles and problems faced by the researcher. This research applied qualitative research design to minimize these things from happening. At least using qualitative research methods, researchers are able to accept the image of the reality to be studied. It also makes it easier to choose variables \& helps in making theories. This article shows that there are many potentials activities and possibilities to be developed in Leang-leang. Furthermore, the development will not put a side of the society. Finally, this article concludes that through the communication, and environmental conservation, tourism activities will be expanded without leaving the community interest.
\end{abstract}

Keywords:

Prehistoric Park, Leang - Leang, Kabupaten Maros, Historical Tourist Destinations

\section{Introduction}

The issue of the environment nowadays has become one of the critical global issues. Young climate change activist Greta Thunberg reveals that today's environmental crisis is caused by the increasing the use of fossil fuels, the increasing human population, and the decreasing forest area around the world (Makmur, 2001). It creates global warming, the destruction of the ecosystem balancing which is marked by the extinction of 
important species that support the balance of the environment. All of these, in the future, will have impact on the survival of human life. Therefore, it needs the strategy, in order that forests can continue to support life, at the same time having an impact on economic, scientific, and socio-cultural development. It is Leang-Leang cave. This concern, about the environment (Halim, Wekke, Zainuddin, Kamaruddin, \& Burchanuddin, 2018).

The Leang-Leang Archaeological Reserve area is a tourist area in Maros Regency which presents traces of ancient relics. The increase in visitors, both from researchers and the community, must be supported by adequate facilities, including the availability of water. Water can be obtained from the origin at the top such as lakes and rivers. In addition, there is also an origin below the top which is commonly known as groundwater (Rohmah et al, 2018). Groundwater is claimed to be of higher quality than upper water because of the above activities. The management of forest areas in Maros Regency is structurally carried out by two institutions. The first, the Forestry \& Plantation Service of Maros Regency, manages \& manages protected forest areas, limited production forests, \& production forests (Nur, 2020). The total area of the three forest areas is 58,738 ha or as much as 86.7 percent of total forest area of Maros Regency. The second, the Natural Resource Conservation Center (BKSDA) of South Sulawesi I, manages and manages a protected forest area of 28,723 ha (Supratman, 2007).

Indonesia's protection forests have a crucial function in protecting the world's ecosystems \& biodiversity. As a country using the third largest forest area in Brazil \& Zaire, Indonesia's forest function in protecting local, national, regional \& world ecosystems has been widely recognized. From the function of biodiversity, Indonesia is well known living around $17 \%$ of the world's species, although its area is only 1.3 of the world's area. It is calculated that Indonesia has 11\% known species of flowering flora, $12 \%$ mammals, $15 \%$ amphibians and reptiles, 17\% bird species and approximately 37\% fish species found in the world (KLH \& UNESCO, 1992).

This special forest will, one day, become extinct and disappear if the management of the protection forest is not carried out in a wise and sustainable manner, as well is supported by clear administration, laws and regulations. Since the the rise of decentralized authority administration through Regulation No. 22/1999 which has been revised by Regulation No. 32/2004, not all protection forest management is authorized by Jakarta, some is authorized by the region. The granting of this authority is a task as well as a challenge for regional governments to be able to manage forests in their regions for the prosperity of their regions from the principle of sustainability. (Ginoga, Lugina, \& Djaenudin, 2005). One of the current forest management struggles is a public relations problem between various interests, resulting from the misalignment of the output of the mix between the tidying up of forest areas and the Provincial/District Spatial Planning (RTRWP/RTRWK). The unsynchronized perception of decentralization has also resulted in poor forest management and security, as well as increased efforts to increase regional income. The unclear boundaries of authority between the center and the regions have also resulted in the throwing of obligations. (Siscawati, 2014).

Under the pretext of increasing Regional Original Income (PAD), several regional governments are trying to shift the function of protected forests \& nature reserves as production forests and even change the status of forest sites as areas for other uses (Setyowati, 2003). The formation of a forest management unit area based on the physical homogeneity of the area, for example above, has resulted in a relatively large area of the management unit, resulting in management inefficiency. This will have an impact on forest management performance. Therefore, it is necessary to analyze the interaction of the structure of the forest management area with the performance of forest management. This study aims to analyze the structure of forest management areas and forest management performance in Maros Regency, South Sulawesi Province.

Leang-Leang Prehistoric Park which is located on a row of steep limestone hills is a tourist attraction that has very interesting historical values. In this place, tourists can see various kinds of ancestral relics, such as prehistoric paintings in the form of pictures of pigs and deer and dozens of pictures of palms attached to the walls of the cave (Hayati, 2013). Entering the Leang-Leang area means not only enjoying the beauty of tropical forests, breathing fresh air, and watching endemic butterflies fly, but also reaching the timelines of thousands of people as far back as decades ago. Tourists will enjoy the monumental discoveries in the world of archeology that the world has ever seen. These archaeological finds are protected, and can be widely accessed by both domestic and international tourists. Its location which is not far from the Makassar-Bone axis road and is not disturbed by traffic noise makes Leang-Leang a natural tourism destination as well as a science adventure. Tourists can get up close and personal with an archaeologist and understand this amazing prehistoric civilization.

The maroon colored pictures are made from natural materials that are difficult to erase. According to hand experts, the palm image belongs to one of the tribe members who had followed the finger cutting ritual 
as a sign of mourning the death of a loved one. In addition, visitors can also see various tools made of stone, food scraps in the form of animal bones and marine objects in the form of shells in large numbers. On one of the rocks at the mouth of the cave, it is clear that there are seashells attached to the rock of the cave. Experts estimate that centuries ago Maros Regency was an ocean that was united with the Java Sea. (Ery, 2018).

Previous research shows the development of environment (Anriani, Halim, Zainuddin, Wekke, \& Abdullah, 2018). Around the Leang-Leang Prehistoric Park there are also many other caves that have different characteristics and store prehistoric relics with each uniqueness, such as: Leang Bulu Ballang which stores a number of molluscs, porcelain and pottery, and the walls can be used as a rock climbing area; Leang Cabu which has often been used as a training ground for rock climbers, and in front of the mouth of this Leang, you can see limestone mining activities and a large expanse of rice fields and Leang Sampeang which has its own uniqueness that other Leang does not have, namely there is a black human image. All of these huts are relatively close to each other, making them easy to visit. The road to that place is not very good, but the scenery around it is very beautiful. Big black rocks are piled neatly in a wide field or in a stretch of rice fields with very distinctive characteristics from the area around the Leang-leang cave (Halim, 2016). This article will identify the tourism side of Leang-leang in term of environmental conservation.

\section{Methods}

The method used in this case is a qualitative method. Analyzing data in qualitative research methods is to collect data. So that the data can be reduced, data reduction is an effort to conclude the data, then sort the data into certain concept units, certain categories, and also certain themes (Rijali, 2018). The results of data reduction are processed in such a way so that the figure looks more complete. It can be in the form of sketches, synopsis, matrices, and other forms; it is very necessary to facilitate the presentation and affirmation of conclusions. The process, of course, does not happen once, but interacts back and forth. Only then are the data presented, then concluded and then verified (Rijali, 2019).

In this qualitative method, besides aiming to facilitate researchers in conducting a study, it also aims to be able to find out the facts that have been raised by researchers (Sholihah, \& Afriansyah, 2017). It is undeniable that when conducting a research, there are always obstacles and problems faced by the researcher. So based on that, qualitative research methods are here to minimize these things from happening. At least using qualitative research methods, researchers are able to accept the image of the reality to be studied. It also makes it easier to choose variables \& helps in making theories (Nirmala et al, 2020).

\section{Results and Discussion}

The area of the existing forest management unit consists of functions, namely, (1) the area of the protected forest management unit for the purpose of preserving the diversity of plants and animals and their ecosystems which also functions as a life support system area, (2) the area of the protected forest management unit for the purpose of regulating water management, preventing flooding, controlling erosion, preventing seawater intrusion, \& maintaining soil fertility, and (3) area of production forest management unit for the purpose of producing forest output (Nur, 2020). These areas were formed from an approach to the physical homogeneity of the area and for the main purpose of protecting soil and water.

Location The protected area in the Maros Regency area based on the MIH Program is 86,141.94. The basis for determining protected areas for the MIH Program is to follow the criteria set out in laws and regulations using the stipulation limits, namely:

a. Areas that place the protection of their subordinate areas include: 1) Protection forest, conservation forest; 2) Production forest with physical characteristics: Altitude $2000 \mathrm{mdpl}$ and/or slurry 40\%; 3) Outside the Protected Forest Area, it has physical characteristics: an altitude of 2000 mdpl \&/or a humidity of 40 is an area prone to landslides.

b. Local Protected Areas include: 1) river borders; 2) lake/reservoir borders; \& 3) the shoreline. The MIH Program protected areas, which are mostly located on slopes $>40 \%$, have been used by residents for cultivation activities. The majority of cultivation activities in slopes $\langle 40>40$ are mixed gardens, namely 35.23 and 40.11 of the protected area. Meanwhile, for settlements, only $0.2 \%$ does not significantly affect environmental requirements, but if it is not anticipated at the outset, settlements will continue. increases in protected areas as population growth continues to increase every year which requires human resources for shelter or for farming to meet their daily needs. The determination of protected areas in the RTRW of South Sulawesi Province 20092029 is: a. Areas that place protection of their subordinate areas including protected areas in forest areas \& protected areas outside forest areas include: 1) conservation forests; 2) protected forest \& or other forest areas 
using a score of $>125$ (slope class, soil type, rain intensity); 3) Field slope $>40$ and in areas where the soil is sensitive to erosion using a field slope of more than 25\%; 4) Forest area that has a height of 2000 meters or more above the sea. b. Local Protected Areas include: 1) coastal borders; 2) river border; 3 ) dam border; 4) spring border. 125 (slope class, soil type, rain intensity); 3) Field slope $>40$ and in areas where the soil is sensitive to erosion using a field slope of more than $25 \%$; 4) Forest area that has a height of 2000 meters or more above the sea. b. Local Protected Areas include: 1) coastal borders; 2) river border; 3) dam border; 4) spring border. 125 (slope class, soil type, rain intensity); 3) Field slope > 40 and in areas where the soil is sensitive to erosion using a field slope of more than 25\%; 4) Forest area that has a height of 2000 meters or more above the sea. b. Local Protected Areas include: 1) coastal borders; 2) river border; 3) dam border; 4) spring border.

Environmental improvement aims to balance the spatial arrangement of protected areas and cultivation areas so that they are permanently sustainable, as a result, it is necessary to apply protected area management tactics that are useful for the biological welfare of the people in Maros Regency. The management strategy is carried out using a map of the Program Towards a Green Indonesia (MIH) as a tool for studying the designation of protected areas in Maros Regency because the goal of the MIH Program is to supervise the performance of the district government in the application of laws and regulations in the field of protection of natural resources and control of environmental damage (Suprapto, 2007). The forest management area of Maros Regency is all forest areas in the Maros Regency area that can be managed sustainably, covering an area of 67,779 ha. Based on the function, The forest management area consisted of 25,087 ha of protected forest, 7,886 ha of limited production forest, 25,765 ha of production forest, and 28,723 ha of protection forest. (Yusuf, Subaedah, \& Saida, 2020).

The forest management unit is the smallest forest management unit as a forum for efficient and sustainable forest management activities to achieve the goals that have been set. Referring to the structure of the management area in Law no. 41/1999, the district forest management area is divided into forest management units where each management unit is managed by a management institution that is structurally responsible for the district forestry institution. The management institution in the management unit carries out forest management activities in the field \& implements forestry infrastructure \& development programs that have been formulated by the district forestry institutions (Kartodihardjo, 2006).

The South Sulawesi Provincial Forestry Service is of the opinion that the two government regulations are not too difficult to understand and not too difficult to implement. The two regulations are believed to be relatively consistent, but they are actually believed to be less synchronous using regional requirements. If the regulations have been implemented, it is believed that it can relatively increase stakeholder discipline (Stiawati, 2010). The Pangkep District Forestry \& Plantation Service is of the opinion that PP 6/2007 in conjunction with PP 3/2008 is not too difficult to understand but relatively difficult to implement because it is not in harmony with regional requirements. Regulations are also believed to be incompatible with other regulations, but if they can be applied they can relatively increase stakeholder discipline. While PP 38/2007 is believed to be not too difficult to understand,

If implemented, this regulation can relatively increase stakeholder discipline. The Department of Forestry \& Plantation of Maros Regency is of the opinion that PP 6/2007 in conjunction with PP 3/2008 is not too difficult to understand, but relatively difficult to implement. Regulations are believed to be less in sync with regional requirements \& less compliant with other regulations. This regulation is also believed not to increase stakeholder discipline. Meanwhile PP 38/2007 is believed to be not too difficult to understand but relatively difficult to implement. Regulations are believed to be less in sync with regional requirements \& less compliant with other regulations. If the regulations are implemented, they can relatively increase stakeholder discipline. PP 3/2008 and PP 6/2007 have several regulations on protected forests: Article 23 and Article 3092 concerning community forests around forests. There are three main activities that can be carried out in protected forests: land use, utilization of environmental services, and collection of NTFPs. For every activity that is carried out without changing the protection function, it is necessary to first obtain permission from the competent authority according to the law for a certain time, a certain area and a certain amount of money., the permission was made. expanded as follows: Current clause. On the other hand, Article 92 explains that the utilization of protected forest activities can be carried out through $\mathrm{Hkm}$ activities.

Furthermore, the content of the article is very clear, but because this article aims to improve the health of people living around the forest, some terms are still used, so socialization and explanations need to be carried out by the target community (Beautiful et al, 2010). The regulation also explains that the additional code of ethics will be explained in more detail in the Ministerial Regulation. In addition, the Forestry and Plantation Offices of Pankep and Maros can no longer guarantee follow-up because the regulation is only issued as a 
regional reference after the investigation is complete. PP 38/2007 lists government work in the forestry sector in the appendix. Of the 59 government jobs in the forestry sector, 19 of them are related to protected forest management. Among the 19 tasks of the forestry sector are related to the management of protected forests with a central nuance. The central government's authority includes the development of codes, standards, procedures, and standards for protected forest management practices. The authority of the regional government and the regional/municipal government is limited to the implementation of activities, proposals and technical considerations.

According to information from the Pangkep and Maros Regional Food and Forestry Services, the three issues are actually related to territorial boundaries where many forest communities claim land to be included in the zone area. If there is a problem, we hope that the Global Forestry Office has the authority to take the above actions, as the Global Forestry Office does. On the other hand, if there are special considerations to keep the central government in power, there must be a clear time frame for making decisions on the proposals of local governments. This statement comes when forest conversion proposals, either approved or rejected, fail within two years. there is no difference between legislation and enforcement. This means that open-pit mining is carried out in protected forest areas. Because, Marble mining took place before laws prohibiting this activity were enacted. Miners invest heavily and strongly oppose the enactment of Law 41/1999. In addition, in the provincial forest, Perpu No. There are multiple criteria for the continuation of all fishing activities carried out prior to the enactment of Law 41/1999, of which 1/2004 was promulgated. This turned out to be an exception for the top 13 miners, but no other miners were able to exploit until their license expired. After the license expires This turned out to be an exception for the top 13 miners, but no other miners were able to exploit until their license expired. After the license expires This turned out to be an exception for the top 13 miners, but no other miners were able to exploit until their license expired. After the license expires

There are different interpretations of several terms related to protected forests, such as protected areas and protected forests. SK Director of PHPA No. Director's Decree, 32 of 1990, uses the term protected area. January 29, 1996 uses the term protected area, but the law does. 41/1999 and PP. 34/2002 uses the terms protected forest and protected forest (Indah et al, 2010). Therefore, it is necessary to explain more clearly the division of forest areas into protected forests, conservation areas, and protected forests (Stiawati, 2010).

Clearing between forest and mining. Here, SK 41/1999, PP44/2004 and Permen12/MenhutII/2004 stipulate that land clearing is an effort to restore or restore land and vegetation. Forest animals are affected by forestry activities. Used to function optimally in accordance with Function 1. Although the term TPA was not mentioned in November 1967, perhaps the Joint Mining Bill enacted in 2005 was an effort to improve and restore land/vegetation, environmental quality, facilities and infrastructure, which states that. There is no mention that public infrastructure has been destroyed as a direct result of the mining industry and can be restored or restored to its original state. And the provisions of the law do not explain how conversion and conversion are carried out, and what the sanctions are, but stipulates that management is carried out for environmental management or rehabilitation, there is only Article 46. Activities are carried out by the Minister of Mines, Governors, and Mayors in the administration of government (Najicha, 2021)

The Ministry of Forestry is not involved in this guidance and monitoring. Therefore, he is concerned that there will be differences in perceptions of the results of rehabilitation activities as a result of efforts to rebuild protected forests (Indah et al, 2010). Regulation of the Minister of General Mining Number $336 . \mathrm{K} / 271 / \mathrm{DDJP} / 1996$ is an activity that aims to improve or regulate land use, and is equipped to operate in accordance with its designation and validity. However, it is not stated who built and oversees the regeneration. Therefore, the reclamation plan cannot be implemented. Article 16 even states that if a mining company charges an environmental price, it will benefit from an exemption of 50\% of the amount of landfill security set for the following year.

Natural resource management policies, laws and regulations. Protected forests have a total of more than 83 regulations, most of which are $61 \%$. Among them are Central Regulations, Regional Regulations $21 \%$, Regional Regulations 18\%. Department regulations. There are still different interpretations of related terms. Protected areas and protected forests and protected areas (including regulations) Landfills are subject to laws and regulations. There is dualism in government policy. Establish rules for the protection and conservation of protected areas. But on the other hand, the protected forest Abuse. There is no clear alignment between reasons and policies that can be used as reference material. Management of protected forest in the area is in accordance with indications of changes in the forest (indah et al, 2010). There is a political conflict between the central government and government policies. Please do not refer to local policies in the relevant local regulations. It is as if the same central government issued regional regulations which were canceled Because he violated the above rules. The Ministry of Forestry has the same understanding of the two laws and regulations. Overall 
there seems to be no problem. For Criterion 3 (fulfillment of local conditions) only, the National Forestry Service considers the regulation not appropriate to local conditions. In general, there are three things that can be seen quite related to the two laws above. This means that it is rather difficult to implement, not in accordance with other regulations and not in accordance with local conditions. Implementation is difficult because the potential for protected forests has not been fully identified. These two provisions, contrary to other provisions, not aligned with PP 6/2007 which was combined with PP 3/2008 when linking fairly broad competencies to regions, but PP 38/2007 limited Introduction. The difference in regional conditions means that the two provisions are too concentrated, especially on PP 6/2007 and PP 3/2008 on Java's Forest Conditions so that they are not suitable to be applied. In other areas, forest conditions and personalities are different. People who live around the forest.

The solution does not require the central government to specify the level, time, and mode of activity in detail, and gives regions (diplomas, ex/hours) the possibility of being creative freely according to each person's circumstances. The difference in regional conditions means that the two provisions are too concentrated, especially on PP 6/2007 and PP 3/2008 on Java's Forest Conditions so that they are not suitable to be applied. In other areas, forest conditions and personalities are different. People who live around the forest. The solution does not require the central government to specify the level, time and mode of activity in detail, and gives regions (diplomas, ex/hours) the possibility of being creative freely according to each person's circumstances. The difference in regional conditions means that the two provisions are too concentrated, especially on PP 6/2007 and PP 3/2008 on Java's Forest Conditions so that they are not suitable to be applied. In other areas, forest conditions and personalities are different. People who live around the forest. The solution does not require the central government to specify the level, time and mode of activity in detail, and gives regions (diplomas, ex/hours) the possibility of being creative freely according to each person's circumstances. These findings will has opportunity to accelerate of information technology to society development. (Idris, Willya, Wekke, \& Mokodenseho, 2020).

\section{Conclusion}

Making the potential of protected forests as a tourist attraction is a surplus both in developing the tourism industry, and in an effort to protect the forest as a habitat for hundreds of endemic species in it. Running both is not impossible. Natural tourism as well as science tourism, especially archaeological tourism, is the potential of the Leang-leang archaeological site. This site invites tourists to reach the prehistoric world through the guidance of professional guides, so that visitors have an imagination about these archaeological discoveries, as well as admire the artworks of pre-historic human civilization in responding to nature, society, and the environment. On the other hand, visitors can also enjoy the natural environment, rock hills, endemic butterflies, fresh air, and trees that are hundreds of years old. Leang-Leang's natural facilities provide a sense of relaxation and recreation, as well as an amazing science experience.

The Leang-leang Prehistoric Site as a tourist attraction in Maros Regency, unfortunately, has not been optimally managed, it is necessary to improve good accessibility, add basic facilities $\&$ infrastructure, complete conservation support facilities that are safe, comfortable \& scientifically valuable, it is necessary to continuously improve the services of the apparatus in charge of the object area of prehistoric parks, but also the obstacles that must be identified as a result which can be minimized cases and obstacles in its development.

\section{Reference}

Agrotechno Park Cangar Batu Jawa Timur Berdasarkan Metode Geolistrik Resistivitas, Jurnal Fisika Dan Aplikasinya, 14(1),5.

Andoko Ageng Setyawan 2018 The Effect of Emotional Intelligence on Mathematics Learning Outcomes of Kansai Vocational High School Students Pekanbaru JPPM 11 1 10-18

Anriani, H. B., Halim, H., Zainuddin, R., Wekke, I. S., \& Abdullah, A. (2018). Fisherman's wife role in extending household income in palu gulf. Paper presented at the IOP Conference Series: Earth and Environmental Science, , 156(1) doi:10.1088/1755-1315/156/1/012001

Bukhari, B., Wekke, I. S., Thaheransyah, T., \& Sabri, A. (2019). Anthropocentric religious communication of national amil zakat agency for the empowerment of marginal communities in padang indonesia. International Journal of Innovation, Creativity and Change, 5(2), 1102-1115.

Dewi, I. N., HB, A. R., \& Kusumedi, P. (2010). Implementasi Peraturan tentang Pengelolaan Hutan Lindung: Studi Kasus di Kabupaten Pangkep dan Kabupaten Maros, Sulawesi Selatan. Jurnal Analisis Kebijakan Kehutanan, 7(3), 195-209. 
Ery, A. P. (2018). Pengelolaan Taman Prasejarah Leang-Leang Di Kabupaten Maros Sebagai Destinasi Wisata Sejarah. Barista: Jurnal Kajian Bahasa dan Pariwisata, 5(1), 1-11.

Ginoga, K. L., Lugina, M., \& Djaenudin, D. (2005). Kajian kebijakan pengelolaan hutan lindung. Jurnal Penelitian Sosial dan Ekonomi Kehutanan, 2(2), 169-194.

Halim, H., Wekke, I. S., Zainuddin, R., Kamaruddin, S., \& Burchanuddin, A. (2018). Become entrepreneurs: The social impact of wind power plant industry project. Paper presented at the IOP Conference Series: Earth and Environmental Science, 175(1) doi:10.1088/1755-1315/175/1/012228.

Halim, L. F. (2016). Pengelolaan dan Potensi Eko Wisata di Taman Nasional Bantimurung Bulusaraung. Agrika, 10(2).

Hayati, N. (2013). Upaya Pengamanan Taman Nasional Bantimurung Bulusaraung Melalui Pembangunan Desa Wisata. Buletin Eboni, 10(2), 127-135.

Houghton, J. T., Jenkins, G. J., \& Ephraums, J. J. (1990). Climate Change

Idris, M., Willya, E., Wekke, I. S., \& Mokodenseho, S. (2020). Peace resolution in education and application on information and communication technologhy. International Journal of Advanced Science and Technology, 29(6), 3349-3358.

Kartodihardjo, H. (2006). Masalah Kapasitas Kelembagaan dan Arah Kebijakan Kehutanan: Studi Tiga Kasus (Problem of Institutional Capacity and Direction of Forestry Policy: Three Cases Study). Jurnal Manajemen Hutan Tropika, 12(3).

Makmur, Z., Arsyam, M., \& Delukman, D. (2021). The Final Destination's uncomfortable vision to the environmental ethics. Journal of Advanced English Studies, 4(2), 76-82.

Mujahid, I., Minsih, M., Ghafur, W. A., \& Wekke, I. S. (2019). Teaching and learning in inclusive classroom; case in elementary school. Journal of Advanced Research in Dynamical and Control Systems, 11(8 Special Issue), 557-568.

Najicha, F. U. (2021, August). Dampak Kebijakan Alih Fungsi Kawasan Hutan Lindung Menjadi Areal Pertambangan Berakibat Pada Degradasi Hutan. In Proceedig Of Conference On Law And Social Studies (Vol. 2, No. 1).

Nasir Zakaria, G. A., Nawi, A., \& Wekke, I. S. (2019). The effectiveness of implementing noble values through online problem-based learningamong students in higher learning institution. Journal of Advanced Research in Dynamical and Control Systems, 11(8 Special Issue), 540-556.

Rijali, A. (2018). Analisis Data Kualitatif, Jurnal Ilmu Dakwah,17(33).

Rijali, A. (2019). Analisis data kualitatif. Alhadharah: Jurnal Ilmu Dakwah, 17(33), 81-95.

Rohmah, S.A., Maryanto, S. dan Susilo, A. (2018).Identifikasi Air Tanah Daerah

Setyowati, F. M. (2003). Hubungan keterikatan masyarakat kubu dengan sumberdaya tumbuh-tumbuhan di Cagar Biosfer Bukit Duabelas, Jambi. 5447.

Sholihah, S. Z., \& Afriansyah, E. A. (2017). Analisis kesulitan siswa dalam proses pemecahan masalah geometri berdasarkan tahapan berpikir Van Hiele. Mosharafa: Jurnal Pendidikan Matematika, 6(2), 287 298.

Siscawati, M. (2014). Pertarungan penguasaan hutan dan perjuangan perempuan adat. Jurnal Wacana Nomor, $33,159-197$.

Stiawati dkk. (2010). The management of Protected Area in Maros Regency, jurnal unhas, 1(1).

Supratman, S. (2007). Analisis Struktur Wilayah dan Kinerja Pengelolaan Hutan di Kabupaten Maros, Provinsi Sulawesi Selatan. Jurnal Hutan dan Masyarakat, 2(2), 8201.

Supratman. (2007). Analisis Struktur Wilayah dan Kinerja Pengelolaan Hutan Di kabupaten Maros, Provinsi Sulawesi Selatan, Jurnal Hutan dan masyarakat, 2(2).

Yusuf, M., Subaedah, S., \& Saida, S. (2020). Strategi Pengelolaan Hutan Rakyat Di Kabupaten Maros. Agrotek: Jurnal Ilmiah Ilmu Pertanian, 4(2), 65-78.

\section{Biographies}

Ismail Suardi Wekke is alecturerat Postgraduate Program in the Department of Islamic Education, State Islamic Institute (IAIN) Sorong, Indonesia, where he serves as chair (2020-2021). Ismail was born in the village namely Camba. A village in Maros Regency, South Sulawesi, Indonesia. His areas of interest and research range in various topics, including teaching and learning, sociolinguistics, and multicultural education.

Muhammad Makbul, a teacher of Islamic Religious Education at the 5 Makassar State Senior High School, as well as a lecturer at the DDI Islamic College of Makassar City, and now continuing his doctoral education 
at the Alauddin State Islamic University of Makassar. Currently Makbul is broadening his experience at the Himpunan Mahasiswa Islam, PERDANA Institute, Elstudika Indonesia, managing journals, writing articles, researching.

Amin Rais, undergraduate student Universitas Islam Negeri Alauddin Makassar, Indonesia. Recently, staf at Institut Sains dan Teknologi An-Nuriyah Makassar, Indonesia. He chaired Dewan Eksekutif Mahasiswa, faculty of Education and Teacher Training, Universitas Islam Negeri Alauddin Makassar, Indonesia. Among his activities is Himpunan Mahasiswa Islam.

Zulkifli Makmur, lecturer in Sekolah Tinggi Agama Islam Darul Dakwah Wal Irsyad Kota Makassar, Indonesia. Graduated from Universitas Gadjah Mada, Indonesia. He earned his undergraduate from Universitas Islam Negeri Alauddin Makassar, Indonesia. During his undergraduate program, he was general secretary of Himpunan Mahasiswa Islam Cabang Gowa Raya.

Sirajuddin Sirajuddin, senior lecturer Universitas Pendidikan Muhammadiyah Sorong, West Papua, Indonesia. He is deputy rector for cooperation. The university was Sekolah Tinggi Keguruan dan Ilmu Pendidikan Muhammadiyah Sorong. He is in charge of management for international activities and for student and lecturer recognition. 